\title{
Epidemiological Study on Acute Diarrheal Disease of Children and Adolescents in the Jeju Region Using a Multiplex-PCR
}

\author{
Kyu-taeg Lee ${ }^{1}$, Sunmi Kim², Moo Sang Chong ${ }^{3}$ \\ ${ }^{1}$ Department of Laboratory Medicine, Cheju Halla General Hospital, Jeju, Korea \\ ${ }^{2}$ Department of infection Control Service Team, Cheju Halla General Hospital, Jeju, Korea \\ ${ }^{3}$ Department of Clinical Pathology, Cheju Halla University, Jeju, Korea
}

\section{Multiplex-PCR을 이용한 제주지역 소아청소년의 급성설사질환 역학조사}

이규택 ${ }^{1}$, 김선미 $^{2}$, 정무상 $^{3}$

${ }^{1}$ 제주한라병원 진단검사의학과, ${ }^{2}$ 제주한라병원 감염관리실, ${ }^{3}$ 제주한라대학교 임상병리과

\begin{abstract}
To examine the cause of acute diarrheal disease in children and adolescents, 521 fecal samples underwent multiple-PCR for a period of two years, between March 2015 and February 20178, in the Jeju region of Korea. Based on the analysis of 179 positive samples, 102 samples were male (56.98\%) and 77 were female (43.02\%), and highest positive rates were shown in the age group of $3 \sim 4$ years $(51.96 \%)$ and $5 \sim 6$ years $(12.29 \%)$. When 209 cases $(40.12 \%)$, including double infection were analyzed, there were 88 cases $(16.89 \%)$ of norovirus-GII infection, 26 cases $(4.99 \%)$ of Campylobacter spp. infection, 18 cases (3.45\%) of rotavirus infection, 18 cases $(3.45 \%)$ of Clostridium difficile Toxin B infection, 17 cases (3.26\%) of adenovirus infection, 16 cases (3.07\%) of Clostridium perfringens infection, 11 cases $(2.11 \%)$ of astrovirus infection, 5 cases $(0.96 \%)$ of Salmonella spp. infection, 3 cases (0.58\%) of norovirus-GI, Yersinia spp. and Aeromonas spp. infections, and 1 case $(0.19 \%)$ of verocytotoxin-producing $E$. coli infection. Based on a seasonal separation of early childhood, norovirus-GI and norovirus-GII mainly prevailed during the winter, when the temperature is low. Typical enteritis with an increased prevalence of rotavirus during the spring. Astrovirus prevailed between the months of April and October, when norovirus-GI, norovirus-GII, and rotavirus did not prevail. With increasing age, acute diarrheal disease was not only induced by a virus, but also by bacteria. Although a test for virus is an effective method when trying to identify the cause during early childhood by multiplex-PCR, it would be desirable to undergo tests for both virus and bacteria concurrently as age increases.
\end{abstract}

Key words: Diarrhea, Gastroenteritis, Multiplex-PCR

This is an Open Access article distributed under the terms of the Creative Commons Attribution Non-Commercial License (http://creativecommons.org/licenses/by-nc/4.0) which permits unrestricted non-commercial use, distribution, and reproduction in any medium, provided the original work is properly cited.

Copyright (c) 2017 The Korean Society for Clinical Laboratory Science. All rights reserved.
Corresponding author: Moo Sang Chong Department of Clinical Pathology, Cheju Halla University, Halla University, Jeju Special Self-Governing, Rd. 38, Halladaehak-ro, Jeju 63092, Korea

Tel: 82-64-741-6732

Fax: 82-64-741-6729

E-mail: chong@chu.ac.kr

Received: May 6, 2017

Revised $1^{\text {st. }}$ June 1, 2017

Revised 2 ${ }^{\text {nd }}$ : June 8, 2017

Accepted: June 8, 2017
서 론

급성설사질환은 영 · 유아에서 호흡기 감염 다음으로 흔한
질환이며, 사회 경제적인 발전과 더불어 환경 위생과 영양 상태 가 좋아짐에 따라 발병률이나 사망률은 급격히 감소하였으나 야채 및 과일 섭취의 증가, 각 국가 간 활발한 농수산품의 거래, 
외식 산업의 증가에 기인되어 매년 높은 발생률을 보이는 감염 성질환이다[1-3].

많은 나라에서 급성설사질환 관련 감시사업을 수행하고 있으 며, 유럽연합은 36개국의 국가표준실험실(National Reference Lab)이 참여하는 엔터넷(EnterNet)을 운영하고 있으며[4], 미국 은 감시체계로 푸드넷(FoodNet)을 호주는 식품매개질환에 대 한 감시체계로 오즈넷(OzFoodNet)을 운영하고 있고[5], 캐나 다에서는 NESP (National Enteric Surveillance Program)와 C-EnterNet이 유기적으로 운영되고 있다[6]. 일본에서는 국립 감염병연구소(NIID)가 중심이 되어 병원체 검출 정보 자료를 제공하고 있다. 국내에서는 1972년부터 질병관리본부 주관으 로 전국 보건소와 시 ·도 보건환경연구원, 질병관리본부 실험 실을 연계한 급성 설사 질환 원인병원체에 대한 검사 업무를 수 행하였으며, 2003년부터는 급성설사질환 실험실 감시사업(엔 터넷, EnterNet-Korea)을 수행하고 있다[7].

이처럼 급성설사질환은 세균 및 바이러스에 의한 감염성 원인 이 있으며, 항생제 사용과 관련된 설사, 장외성 설사, 식이성 설 사, 식품알레르기 등에 의한 비감염성 설사가 있다. 이중 비세균 성 설사질환의 주요 병원체인 바이러스는 노로바이러스 (norovirus), A형 로타바이러스(type A rotavirus), 장관 아데노 바이러스(enteric adenovirus), 아스트로 바이러스(astrovirus), 사포바이러스(sapovirus) 등이 주로 알려져 있으며[8,9], 세균성 설사질환의 주요 병원체로는 살모넬라균(Salmonella spp.), 병 원성대장균(EHEC, ETEC), 세균성 이질균(Shigella spp.), 장염 비브리오균(V. parahaemolyticus), 캠필로박터 제주니(C. jejuni) 등이 주로 알려져 있다[10-12].

노로바이러스에 의한 급성 위장관염의 증상은 $24 \sim 48$ 시간 정도의 잠복기에 따른 갑작스런 구토와 복통이 특징이고, 특히 소아의 경우 설사가 지연되어 나타날 수 있으며 그 외에 두통, 근 육통, 오한, 열 등의 증상이 나타날 수 있으며, 로타바이러스의 주 증상은 발열, 구토 그리고 설사이며, 1 3일의잠복기를 거쳐 경 중증도의 발열과 구토, 복통이 하루 나타나고, 이어 잦은 수양성 설사가 나타난다. 아스트로바이러스는 초기 가벼운 설사가 2 3 일 정도 지속되며 구토, 발열, 식욕결핍, 복통 등의 증상이 동반 된다. 그러나 드물게는 지속적인 설사와 바이러스 배출이 일어 나는 경우도 관찰되며, 임상증상만으로 로타바이러스와의 감염 을 구별하기는 어렵다. 장관 아데노바이러스의 잠복기는 약 7 8일이며, 전형적으로 감염은 5 12일 동안 지속되며, 구토의 빈 도는 낮으며 증상도 더 경미하다. 가장 주요한 임상적 특징은 묽 은 설사변과 설사 1 2일 후에 나타나는 구토이다[13-16].

살모넬라는 6 72시간의 잠복기를 거쳐서 갑자기 시작하는
구역, 구토, 경련성 복통에 수양성 또는 점액 성분이나 혈액성분 을 포함하는 이질성 설사를 동반하고, 발열이 나타나기도 하며, 대변의 특징은 다핵구와 잠혈을 나타낸다. 병원성대장균은 발 병특성, 독소의 종류 등에 따라 통상 5 가지로 분류하며, 장출혈 성대장균의 뚜렷한 특징은 장내에서 출혈성 설사를 유발하고 요독성 요로감염증(Hemolytic Uremic Syndrom)을 동반하는 임상증상을 보이는 병원성대장균으로서 가장 위해도가 높은 것 으로 알려지고 있다[17,18]. 세균성 이질균은 O항원에 의하여 4가지의 혈청군으로 구분되어지며 증상은 전신적인 증상은 동 반하지 않으면서 약간 무른 변이 며칠 지속이 되는 경미한 설사 로부터 심한 경우는 고열, 기면, 복통, 다량의 수양성 설사가 나 타나고 일부는 더 진행이 되어 구토, 구역, 뒤묵직(tenesmus)과 동통을 동반하면서 소량의 점액성 혈변을 배출한다. 장염비브 리오균은 잠복기는 짧은 경우 2 3시간 만에 식중독이 나타나 며, 때로는 수일 경과 후에 발생하기도 하지만 보통 12 시간 정도 에 대부분 발병한다. 증상은 주로 심한 복통을 동반하는 설사이 며, 발열이나 구토, 위장관염 등이 나타나기도 하며, 물과 같은 설사를 하지만 중증일 경우는 혈변이나 점액변이 나와 이질과 혼동되기도 한다. Campylobacter jejuni는 산소에 민감하여 최적 산소농도는 5\% 정도이며, 산소농도가 $21 \%$ 정도인 대기 중 에서는 서서히 사멸한다. 잠복기는 2 3일 정도로 긴 편이며, 주요 증상은 설사이며, 보통 발열, 복통, 근육통, 권태감, 현기 증, 구역질 등의 증세를 보인 후에 설사를 한다[19-21].

본 연구에서는 2015 2016년도 급성설사질환 원인규명을 위해 제주특별자치도에 위치한 $\mathrm{H}$ 종합병원 소아청소년과에서 multiplex PCR 검사가 의뢰된 검체를 통해 확인된 5종의 바이 러스와 10종의 세균에 대한 발생빈도와 유행양상과 유아기(6 세 이하)의 원인별, 계절별 분리양상을 살펴보고자 한다.

\section{재료 및 방법}

\section{1. 대상}

2015년 3월부터 2017년 2월까지 2년간 급성설사질환 원인 규명을 위해 제주특별자치도에 위치한 $\mathrm{H}$ 종합병원 소아청소년 과 외래 및 병동에서 의뢰된 521 분변 검체를 대상으로 조사하 였다. 설사를 주 증상으로 하는 환자의 분변을 48 시간 이내에 $1 \mathrm{~g}$ 이상을 채취하였으며, 분변 채취가 어려운 경우에는 면봉으 로 직장 $\mathrm{swab}$ 을 실시하여 검체를 채취하였다.

\section{2. 방법}

분변에서 Seeplex ${ }^{\circledR}$ Diarrhea ACE detection kits 
(Seegene, Seoul, Korea)를 이용하여 multiplex PCR 검사 방 법을 통해 group A rotavirus (RotV), enteric adenovirus (AdV), norovirus GI/GII (NoV-GI/GII), astrovirus (AstV) 5 종의 바이러스 검사와 Salmonella spp. (Sal), Shigella spp. (Shi), Vibrio spp. (Vib), Campylobacter spp. (Cam), Clostridium difficile Toxin B (CDB), Clostridium perfringens (Clo), Yersinia enterocolitica (Yer), Aeromonas spp. (Aer), E. coli $\mathrm{O} 157: \mathrm{H7}$ (Eco), verocytotoxin-producing E. coli (VTEC)를 포함한 10종의 세균 검사를 실시하였다. 521 분변 검 체 중 바이러스나 세균이 확인된 소아청소년 170 명 중 중복 감 염이 확인된 9 명의 검체를 포함하여 179 개의 양성 검체의 결과 를 분석하였다. 521 검체는 5 종의 바이러스 검사만 의뢰한 경우 는 236건(45.30\%), 10 종의 세균 검사만을 의뢰한 경우는 120

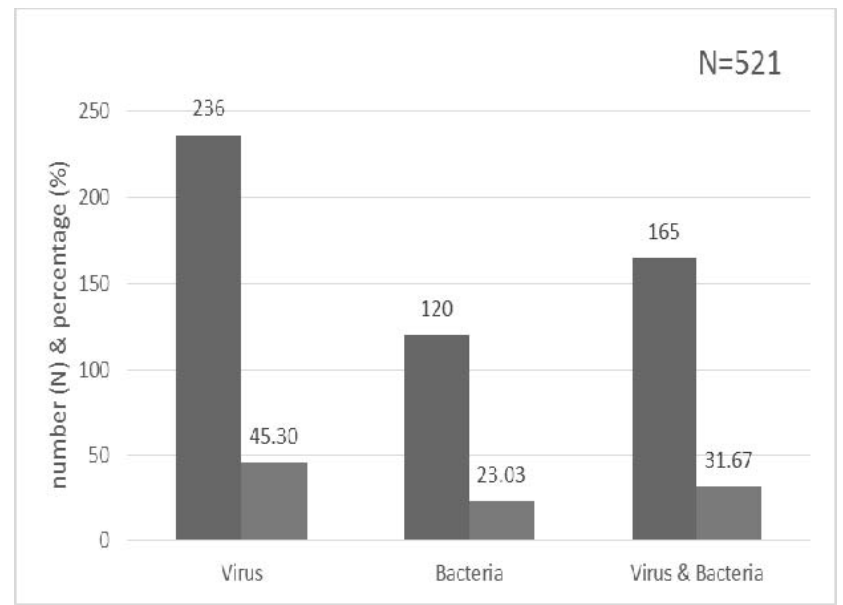

Figure 1. Sample distribution of acute diarrheal disease test on children and adolescents of Jeju region, 2015 2016.
건(23.03\%), 15종의 바이러스와 세균 검사를 의뢰한 경우는 165건(31.67\%) 이었다(Figure 1). 모든 실험 결과는 excel program을 이용하여 분석하였다.

\section{결 과}

\section{1. 연령별 분포}

2015 2016년도 소아청소년과 설사환자에서 수집된 분변 검체 중 급성설사질환의 원인 바이러스나 세균 등을 동시에 여 러 종류를 검출할 수 있는 multiplex-PCR 검사를 의뢰한 검체 는 총 521건이며, 연령별 분포는 2세 이하(15.93\%), 3 4세 (43.95\%), 5 6세(12.09\%), 7 8세(10.75\%), 9 10세(3.07\%), 11 12세(4.41\%), 13 14세(1.73\%), 15 16세(2.69\%), 17 18세(1.92\%), 19 20세(3.45\%)의 환자군에서 수집되었다. 그 중 양성 검체는 총 179 건으로 2 세 이하(10.61\%), 3 4세 (51.96\%), 5 6세(12.29\%), 7 8세(9.50\%), 9 10세(4.47\%), 11 12세(3.35\%), 13 14세(1.68\%), 15 16세(2.79\%), 17 18 세(1.68\%), 19 20세(1.68\%)의 환자군에서 수집되었으며, 3 4 세 환자군에서 양성율이 가장 높은 것으로 조사되었다(Figure 2).

바이러스 검사만 의뢰한 경우 89건 양성 검체의 연령별 분포 는 2세 이하(13.48\%), 3 4세(71.91\%), 5 6세(7.87\%), 7 8세 (3.37\%), 9 10세(0.00\%), 11 12세(1.12\%), 13 14세(1.12\%), $15 \sim 16$ 세 $(0.12 \%), 17 \sim 18$ 세( $0.00 \%), 19 \sim 20$ 세 $(0.00 \%)$ 의 분 포를 보였으며, 세균 검사만 의뢰한 경우 25건 양성 검체의 연령 별 분포는 2세 이하(0.00\%), 3 4세(24.00\%), 5 6세(16.00\%), 7 8세(16.00\%), 9 10세(8.00\%), 11 12세(4.00\%), 13 14 세(8.00\%), 15 16세(12.00\%), 17 18세(4.00\%), 19 20세
(A)

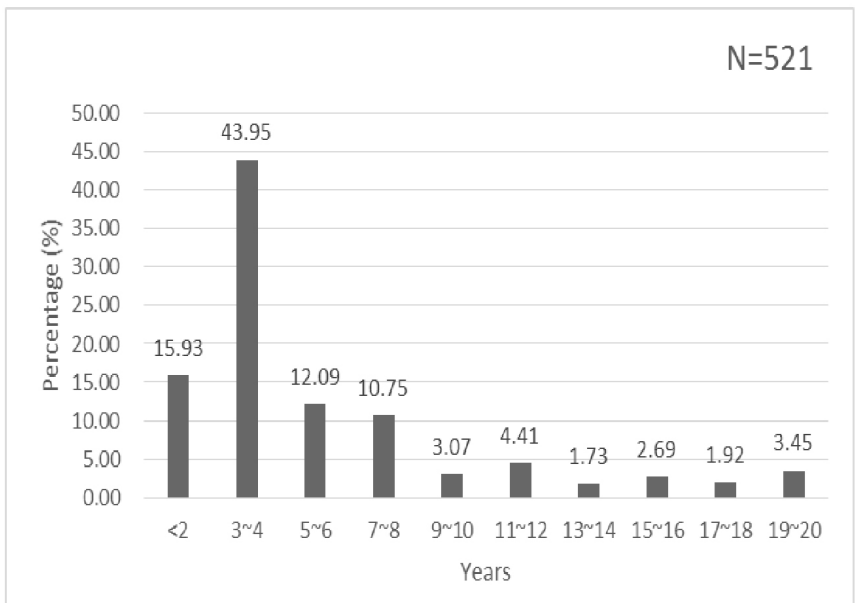

(B)

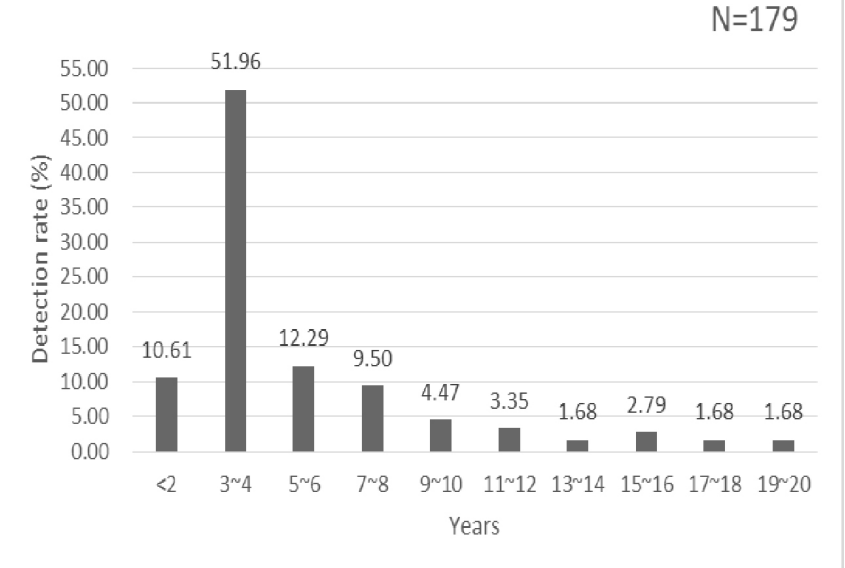

Figure 2. Age distribution of acute diarrheal disease test on children and adolescents of Jeju region. (A) All samples. (B) Positive samples. 
(8.00\%)의 분포를 보였다. 또한 바이러스와세균 검사를 의뢰한 경우 65건 양성 검체의 연령별 분포는 2세 이하(10.77\%), 3 4 세(35.38\%), 5 6세(16.92\%), 7 8세(15.38\%), 9 10세(9.23\%), 11 12세(6.15\%), 13 14세(0.00\%), 15 16세(1.54\%), 17 18세(3.08\%), 19 20세(1.54\%)의 분포를 보였다(Figure 3).

5종의 바이러스 검사만 의뢰한 경우는 3 4세(71.91\%), 2세 이하(13.48\%), 5 6세(7.87\%) 순으로 양성율이 높았으며, 10 종의 세균 검사만을 의뢰한 경우는 3 4세(24.00\%), 5 6세 (16.00\%), 7 8세(16.00\%) 순으로 양성율을 보였으며, 15종의 바이러스와 세균 검사를 의뢰한 경우는 3 4세(35.38\%), 5 6 세(16.92\%), 7 \%세(15.38\%) 순으로 양성율이 높은 것으로 나 타났다.

\section{2. 바이러스와 세균 감염 분포}

양성 검체 총 179 건 중 남아가 102 명(56.98\%), 여아가 77 명 (43.02\%)이었으며, 바이러스 검사만 의뢰한 경우는 89 건

(A)

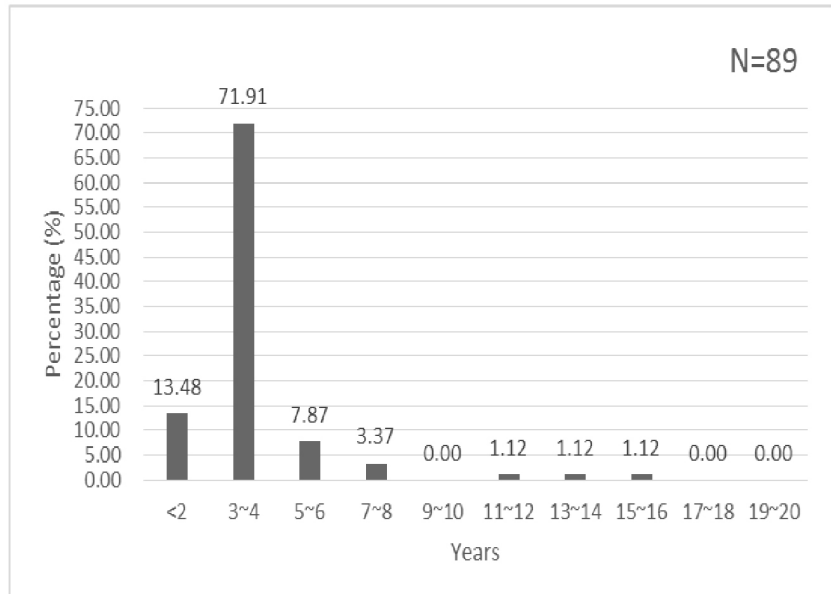

(C)

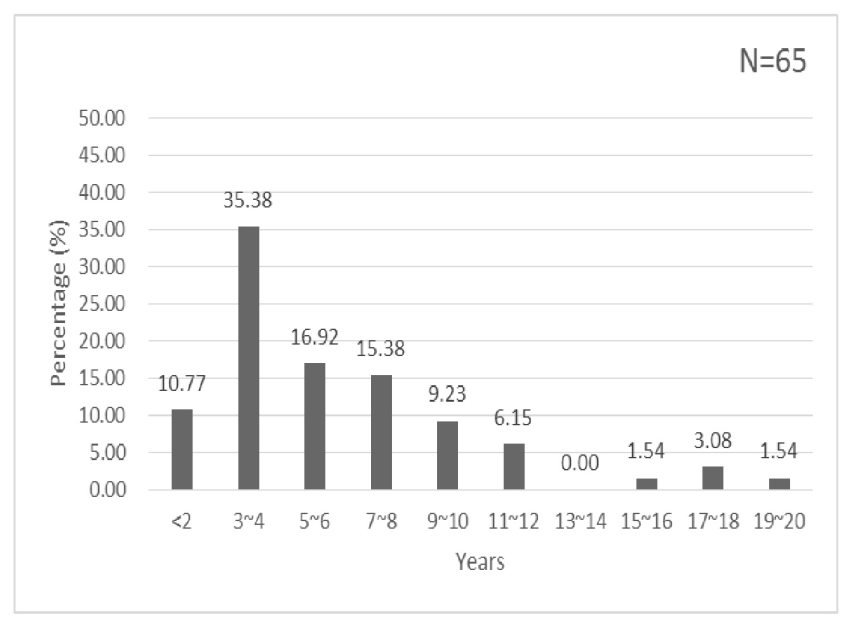

(49.72\%), 세균 검사만 의뢰한 경우는 25건(13.97\%), 바이러스 와 세균 검사를 의뢰한 경우는 65건(36.31\%)으로 양성율을 나 타냈다. 179건의 양성 검체 중 중복감염을 포함한 209건 (209/521, 40.12\%)을 분석한 결과 $\operatorname{RotV}$ 감염은 18 건(18/521, $3.45 \%), \mathrm{NoV}-\mathrm{GI}$ 감염은 3 건(3/521, $0.58 \%), \mathrm{NoV}-\mathrm{GII}$ 감염은 88 건(88/521, $16.89 \%), \mathrm{AstV}$ 감염은 11 건(11/521, 2.11\%), $\mathrm{AdV}$ 감염은 17 건(17/521, 3.26\%), Cam 감염은 26건(26/521, $4.99 \%)$, Sal 감염은 5 건(5/521, $0.96 \%), \mathrm{CDB}$ 감염은 18 건 (18/521, 3.45\%), Yer 감염은 3건(3/521, 0.58\%), Aer 감염은3 건(3/521, 0.58\%), VTEC 감염은 1건(1/521, 0.19\%), Clo 감염 은 16 건(16/521, 3.07\%)으로 분리율을 보였으며, Vib, Eco, Shi 감염에 대한 양성 검체는 발견되지 않았다(Figure 4).

급성설사질환 원인 분석으로 바이러스 검사만 의뢰한 경우 는 236건 중 89건(89/236, 37.71\%)이 양성을 보였으며, 89건 중 81건은 한 가지 바이러스 단독 감염이었으며, 8 건은 두 가지 바이러스 중복감염으로 나타났다. RotV 감염은 13건(13/97,

(B)

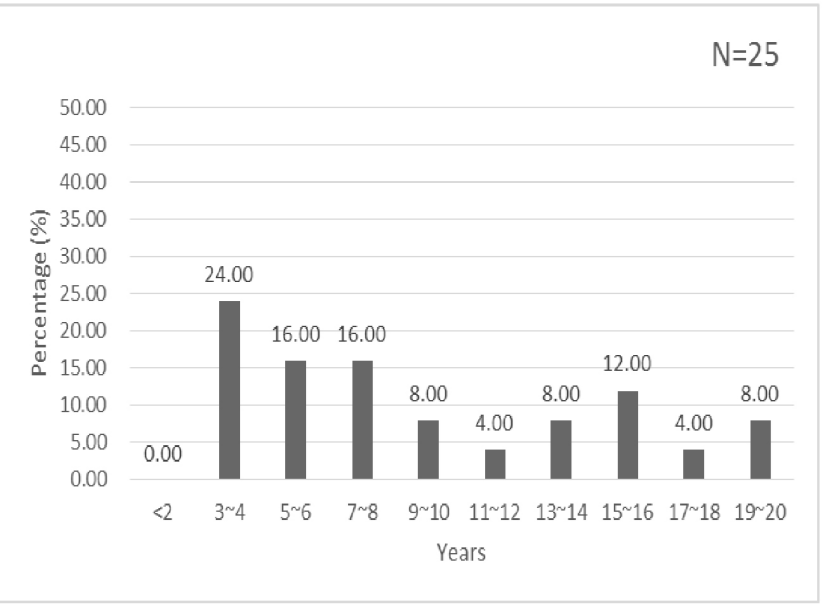

Figure 3. Age distribution of positive samples of acute diarrheal disease in children and adolescents of Jeju region. (A) Virus test only. (B) Pathogenic bacteria test only. (C) Virus test and pathogenic bacteria test at the same time. 


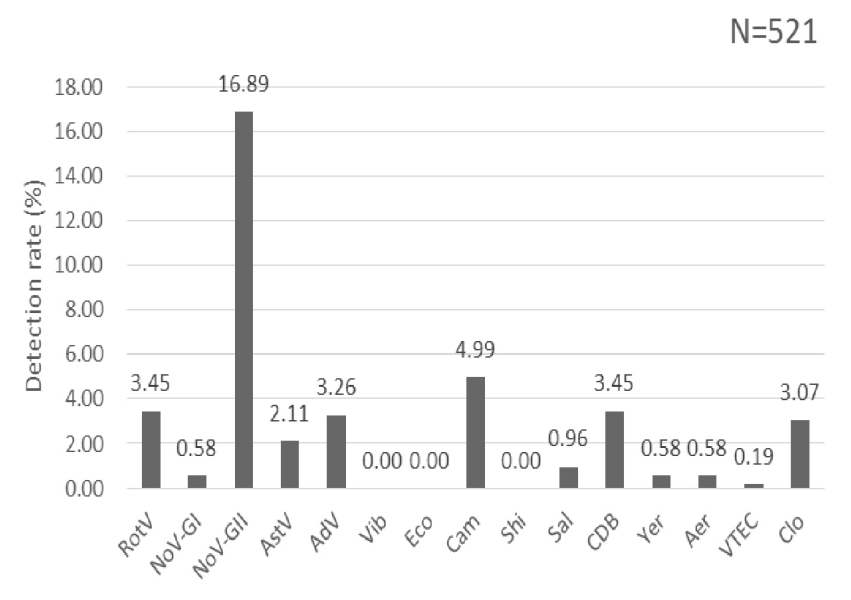

Figure 4. Distribution of causes of acute diarrheal disease in children and adolescents of Jeju region, 2015 2016.

$13.40 \%), \mathrm{NoV}-\mathrm{GI}$ 감염은 2건(2/97, 2.06\%), NoV-GII 감염은 65건(65/97, 67.01\%), $\mathrm{AstV}$ 감염은 6건(6/97, 6.19\%), $\mathrm{AdV}$ 감 염은 11 건(11/97, $11.34 \%$ ) 으로 나타났다. 중복감염의 경우 $\mathrm{NoV}-\mathrm{GII}$ 와 $\mathrm{AdV}$ 감염이 4건, NoV-GII와 AstV 감염이 3건, $\mathrm{NoV}-\mathrm{GII}$ 와 RotV 감염이 1건 이었다.

세균 검사만을 의뢰한 경우는 120 건 중 25 건(25/120, $20.83 \%)$ 이 양성을 보였으며, 세균 감염의 경우 25 건 중 22 건은 한 가지 세균 감염이었으며, 3 건은 두 가지 세균의 중복감염으 로 나타났다. Cam 감염은 9건(9/28, 32.14\%), Sal 감염은 4건 (4/28, 14.29\%), CDB 감염은 9건(9/28, 32.14\%), Yer 감염은 2 건(2/28, $7.14 \%)$, Aer 감염은 3건(3/28, $10.71 \%)$, Clo 감염은 1 건(1/28, 3.57\%)으로 나타났으며, Vib, Eco, Shi, VTEC 감염은 양성을 보인 검체가 없는 것으로 나타났으며, 중복 감염의 경우 에는 Sal와 Aer 감염이 1건, $\mathrm{CDB}$ 와 Aer 감염이 1건, Yer와 Clo 감염이 1건으로 나타났다.

바이러스와 세균 검사를 의뢰한 경우는 165 건 중 65 건 (65/165,36.39\%)이 양성을 보였으며, 2중 중복감염은 RotV와 $\mathrm{AstV}$ 감염이 1건, $\mathrm{NoV}-\mathrm{GII}$ 와 $\mathrm{CDB}$ 감염이 3건, 1 건, $\mathrm{AstV}$ 와 $\mathrm{Clo}$ 감염이 1건, $\mathrm{Adv}$ 와 $\mathrm{Clo}$ 감염이 1건, $\mathrm{Cam}$ 와 $\mathrm{Clo}$ 감염이 2 건, $\mathrm{CDB}$ 와 $\mathrm{Clo}$ 감염이 1 건이었으며, 3 중 중복감염은 $\mathrm{NoV}-\mathrm{GI}$, $\mathrm{NoV}-\mathrm{GII}, \mathrm{CDB}$ 감염과 $\mathrm{Adv}, \mathrm{CDB}, \mathrm{VTEC}$ 감염이 각각 1건으로 나타났다. RotV 감염은 5건(5/78, 6.41\%), NoV-GI 감염은 1건 (1/78, 1.18\%), NoV-GII 감염은 21건(21/78, 26.92\%), AstV 감염은 5건(5/78, 6.41\%), $\mathrm{AdV}$ 감염은 6건(6/78, 7.69\%), Cam 감염은 17 건(17/78, $21.79 \%)$, Sal 감염은 1건(1/78, 1.28\%), $\mathrm{CDB}$ 감염은 8 건(8/78, $10.26 \%)$, Yer 감염은 1건(1/78, $1.28 \%)$, VTEC 감염은 1 건(1/78, $1.28 \%)$, Clo 감염은 12 건
(12/78, 15.38\%)으로 나타났으며, Vib, Eco, Shi, Aer 감염에 대 한 양성 검체는 발견되지 않았다.

\section{3. 월별 분포}

양성 검체 179 건 중 $\operatorname{RotV}$ 감염은 18 건으로 1 월, 3 월에 5건 (27.78\%), 4월에 3건(16.67\%) 순으로 높게 나타났으며, $\mathrm{NoV}-\mathrm{GI}$ 감염은 3건으로 3월, 4월, 12월에 각각 1건(33.33\%), $\mathrm{NoV}-\mathrm{GII}$ 감염은 88건으로 12월, 1월에 13건(14.77\%), 2월, 5 월에 12건(13.64\%) 순으로 나타났으며, $\mathrm{AstV}$ 감염은 11 건으로 5월에 4건(36.36\%), 1월, 6월에 2건(18.18\%) 순이었으며, $\mathrm{AdV}$ 감염은 17 건으로 10 월에 4건(23.53\%), 2월, 8월, 11월에 각각 3건(17.65\%) 순으로 조사되었다.

Cam 감염은 26건으로 7월에 9건(34.62\%), 7월에 4건 (15.38\%), 12월에 3건(11.54\%) 순으로 나타났으며, Sal 감염은 5건으로 6월 2건(40.00\%), 5월, 7월, 9월에 각각 1건(20.00\%), $\mathrm{CDB}$ 감염은 18 건으로 12 월에 6건(33.33\%), 11월에 4건 (22.22\%), 3월, 8월, 10월에 각각 2건(11.11\%), Yer 감염은 3건 으로 5월, 7월, 9월에 각각 1건(33.33\%), Aer 감염은 3건으로 5 월, 6월, 11 월에 각각 1 건(33.33\%), VTEC 감염은 1건으로 10 월에 발생하였으며, Clo 감염은 16건으로 5월에 6건(37.50\%), 8월에 4건(25.00\%), 7월, 10월에 2건(12.50\%) 순으로 조사되 었다(Figure 5).

\section{4. 유아기(6세 이하)의 결과}

179 검체 중 6 세 이하의 연령군에서 양성을 보인 검체는 134 건(74.9\%)이며, 바이러스 2중 중복감염 9건, 세균 2중 중복감염 3 건, 바이러스와 세균의 2중 중복감염 7건, $\mathrm{AdV}, \mathrm{CDB}, \mathrm{VTEC} 3$ 중 중복감염 1건을 포함하여 154 건을 분석한 결과, 바이러스 감 염은 120 건(77.9\%), 세균 감염은 34건(22.1\%)으로 바이러스 감염이 월등히 높은 것으로 조사되었다.

원인별 감염 양상을 보면 $\mathrm{RotV}$ 감염은 17 건(17/521, $3.26 \%$, NoV-GI 감염은 2건(2/521, 0.38\%), NoV-GII 감염은 76건(76/521, 14.59\%), AstV 감염은 10건(10/521, 1.92\%), $\mathrm{AdV}$ 감염은 15 건(15/521, 2.88\%), Cam 감염은 4건(4/521, $0.77 \%)$, Sal 감염은 2 건(2/521, $0.38 \%), \mathrm{CDB}$ 감염은 13 건 (13/521, 2.50\%), Yer 감염은 2건(2/521, 0.38\%), Aer 감염은 2 건(2/521, 0.38\%), VTEC 감염은 1건(1/521, 0.19\%), Clo 감염 은 10건(10/521, 1.92\%)으로 나타났으며, Vib, Eco, Shi 감염 에 대한 양성 검체는 발견되지 않았다.

계절별 분리 양상을 확인한 결과, 기온이 낮은 겨울(11 2월) 에는 주로 NoV-GI, NoV-GII가 유행하였고, 기온이 상승하기 

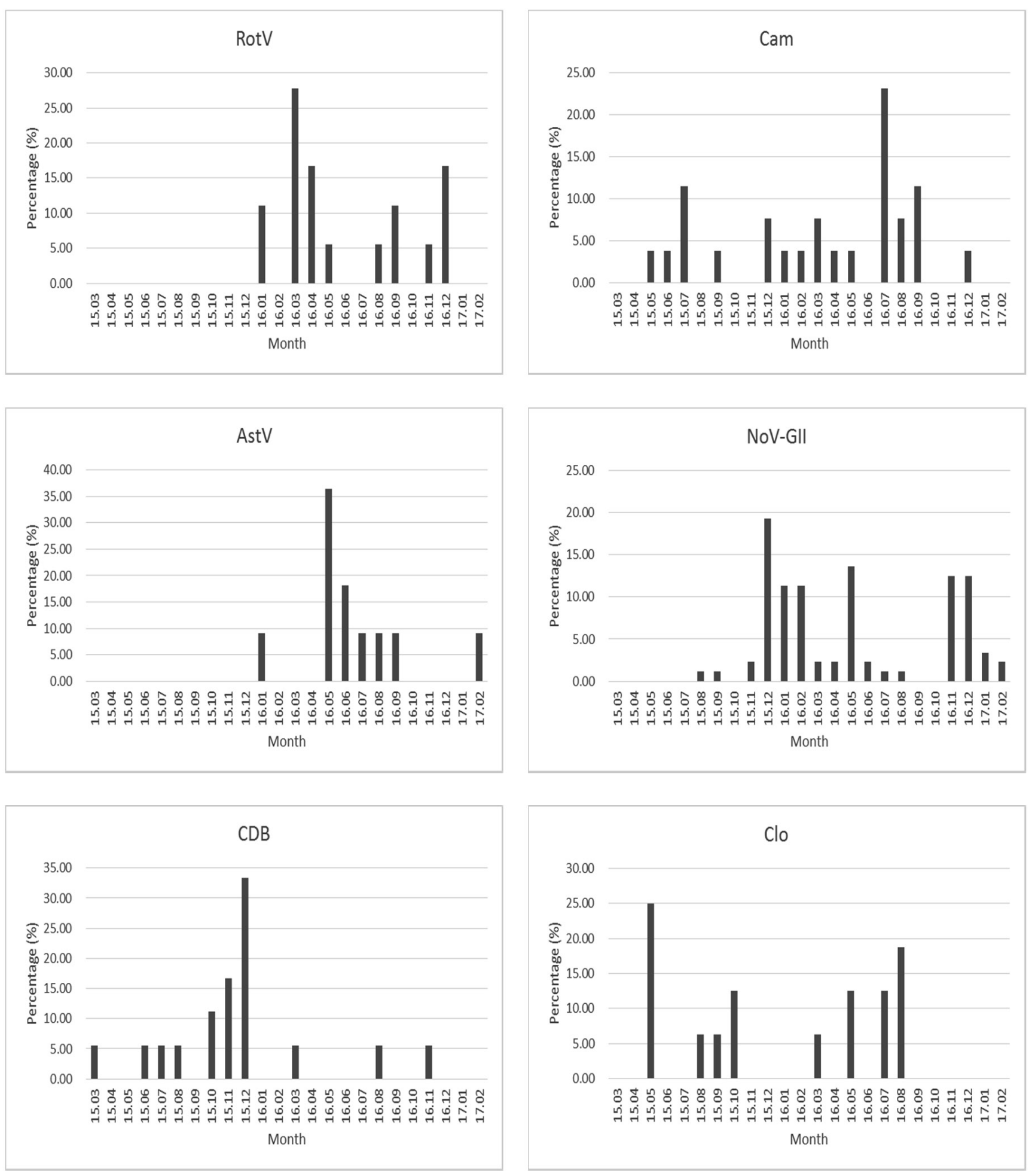

Figure 5. Monthly distribution of acute diarrheal disease in children and adolescents of Jeju region, 2015-2016. Abbreviations: RotV, rotavirus; NoV-GII, norovirus-GIl; AstV; astrovirus, Cam, Campylobacter spp.; CDB, Clostridium difficile Toxin B; Clo, Clostridium perfringens.

시작하는 봄(3 5월)에는 RotV가 유행하는 경향을 전형적인 장염바이러스의 경향을 보였다. $\mathrm{AstV}$ 경우에는 $\mathrm{NoV}-\mathrm{GI}$, NoV-GII, RotV가 유행하는 시기가 아닌 4월 10월에 유행하
는 경향을 보이고, $\mathrm{AdV}$ 인 경우에는 8월 2월까지 유행하는 경 향을 보였다(Figure 6). 
$N=120$

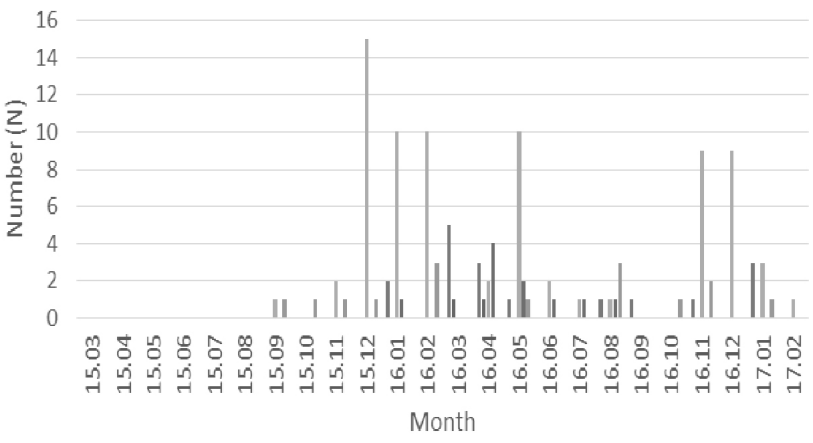

-RoV $\backsim$ NoV-I $=$ NoV-II $\backsim$ AdV $\backsim$ AsV

Figure 6. Monthly distribution of acute diarrheal disease in infants (under 6 years) of Jeju region, 2015 2016.

\section{고 찰}

식품의약품안전처에서 운영하는 식품안전정보포털 '식품안 전나라' 식중독통계에 따르면 2016년 한 해에 7,162명의 환자 와 399건의 식중독이 발생하였다고 보고되어 있으며, 그 원인 은 병원성대장균 2,754명(57건), 노로바이러스 1,187명(55 건), 캠필로박터 제주니 831명(15건), 클로스트리디움 퍼프린 젠스 449명(8건), 살모넬라 354명(21건), 장염비브리오균 251 명(22건), 원충 212명(39건) 순으로 나타났다[22]. 매년 발생율 은 지속적으로 유지되고 있다. 장염(gastroenteritis)은 소장, 대 장에 염증이 생기는 모든 질병을 일컫는 광범위한 용어로, 크게 세균성 장염과 바이러스성 장염으로 분류되며, 대부분의 경우 음식 섭취와 관련이 있기 때문에 식중독과 구분이 어렵다. 식중 독은 식품 또는 물의 섭취에 의해 발생된 것으로 생각되는 감염 성 또는 독소형 질환을 말하며, 급성설사(급성 위장관염, 급성 장염)는 바이러스, 세균, 기생충에 의한 감염. 약제, 독소 등의 원 인으로 위와장에 염증이 발생되어 2주 미만의 설사를 동반하는 질환을 의미한다.

소아 감염성 설사 질환에서 세균성 설사의 빈도는 $10 \%$ 이내 를 차지하고, 일반적으로 세균성과 기생충에 의한 감염은 $20 \%$ 를 넘지 않는 것으로 알려져 있으며, 바이러스성 장염은 $40 \%$ 가 량을 차지하는 것으로 보고되고 있다. 그리고 전체의 약 $1 / 2$ $2 / 3$ 에서는 원인균이 발견되지 않는 비감염성 설사이며, 최근에 는 분자생물학적 진단 기법이 발달 되면서 원인을 발견하지 못 한 위장관염의 원인 분석에 도움을 주고 있다고 보고되고 있다 [23]. 또한 Lee 등[24]의 연구에 의하면 다중 중합효소연쇄반응 법을 이용하여 급성 감염성 설사의 원인세균 13 종 및 바이러스 5 종을 검출한 결과 핵산증폭법과 병원성 세균 배양 결과가 우수
한 일치율을 보였으며, 균종의 동정은 배양 검사법이 기본이 되 므로 이를 대체할 수는 없지만 다중 중합효소연쇄반응법은 직 접 검체에 적용하여 한 번 검사로서 여러 설사원인균 감염에 대 한 선별할 수 있는 장점이 있다고 보고하고 있다[25].

Hwang 등[26]에 의하면 2014년 바이러스성 급성 설사질환 을 조사하기 위해 수집한 검체 14,154 건에서 검출율은 $17.7 \%$ (2,501건)이었다. 이 중 5세 이하 연령대에서 가장 높은 검출율 을 보였고(30.7\%), 그 중 norovirus가 가장 높은 검출율(9.7\%) 을 보이는 병원체였다. A형 rotavirus 또한 높은 검출율(5.0\%) 보였지만, 주로 겨울철에 높은 검출율을 보인 norovirus와는 달 리 1 5월 사이에 높은 검출율을 보였으며, Shim[27]의 연구에 서 질병관리본부의 2011년 기준 국내 급성설사 바이러스 실험 실 감시 결과에 따르면, 5 세 미만 급성설사 환자의 분변 중 약 $30.6 \%$ 에서 바이러스가 확인되었고, 성인까지 전체의 약 $3.4 \%$ 에서 세균이 분리되었다. 바이러스 중에서는 rotavirus가 $15.4 \%$, norovirus 가 $11.6 \%$ 로 가장 많은 비중을 차지하며 그 외 enteric adenovirus 가 $3.0 \%$, astrovirus가 $0.6 \%$ 로 보고되었다. 세균 가운데에는 Salmonella 균속이 가장 많고(2.18\%), 다음으 로 Campylobacter jejuni, 병원성 대장균이 $1 \%$ 미만에서 검출 되었다고 한다. 제주지역에서는 521건 중 34.36\% (179건)으로 다소 높은 검출율을 보였으며, 중복감염을 포함하여 바이러스 감염은 $29.30 \%$ (137건), 병원성 세균 감염은 $13.82 \%$ (72건)로 나타났다. 주요 원인으로는 NoV-GII 감염이 88건(88/521, $16.89 \%)$ 으로 가장 높았으며, Cam 감염이 18건(18/521, $3.45 \%)$, RotV 감염이 18 건(18/521, 3.45\%) 순으로 나타났다. 월별 주요 원인별 분포를 보면, $\operatorname{RotV}$ 감염은 1 5월에 유행하 는 양상을 보였으며, NoV-GII 감염은 주로 11 2월에 유행하 는 양상을 보여 비슷한 경향을 나타냈다. 또한, 유아기(6세 이 하)의 결과는 $25.72 \%$ (134건)의 검출율을 나타냈으며, 중복감 염을 포함한 154 건을 분석한 결과, 바이러스 감염은 120 건 (77.9\%), 세균 감염은 34건(22.1\%)으로 바이러스 감염이 높은 것으로 조사되었으며, 원인별 감염 양상은 NoV-GII, RotV, $\mathrm{AdV}, \mathrm{CDB}, \mathrm{AstV}, \mathrm{Clo}$ 감염 순으로 바이러스가 세균보다 높은 결과를 나타냈다. 계절별 분리 양상을 확인한 결과는 기온이 낮 은 겨울(11 2월)에는 주로 NoV-GI, NoV-GII가 유행하였고, 기온이 상승하기 시작하는 봄(3 5월)에는 RotV가 유행하는 경향을 전형적인 장염바이러스의 경향을 보였다. $\mathrm{AstV}$ 경우에 는 NoV-GI, NoV-GII, RotV가 유행하는 시기가 아닌 4월 10 월에 유행하는 경향을 보이고, $\mathrm{AdV}$ 인 경우에는 8월 2월까지 유행하는 경향을 보였다.

본 실험을 통해 유아기 때에는 바이러스에 의한 급성설사질 
환이 주를 이루고 있으며, 연령이 높아질수록 바이러스뿐만 아 니라 세균이 원인이 되어 급성설사질환을 유발하는 것으로 나 타났으며, 다중 중합효소연쇄반응으로 원인을 파악하고자 할 때에는 유아기 때에는 바이러스 검사를 의뢰하는 것이 유효하 지만 연령이 높아짐에 따라 바이러스와 세균을 동시에 의뢰하 는 것이 바람직하다고 사료된다.

\section{요 약}

2015년 3월부터 2017년 2월까지 2년간 Multiplex-PCR을 이용한 소아청소년의 급성설사질환 원인규명을 위해 의뢰된 521 분변 검체를 대상으로 5 종의 바이러스 검사와 10 종의 세균 검사를 실시한 521 분변 검체 중 바이러스나 세균이 확인된 170 명 중 중복 감염이 확인된 9명의 검체를 포함하여 179 개의 양성 검체의 결과를 분석한 결과 남아가 102 명(56.98\%), 여아가 77 명(43.02\%)이었으며, 3 4세(51.96\%), 5 6세(12.29\%) 연령 대에서 가장 높은 양성율을 보였다. 179 건의 양성 검체 중 중복 감염을 포함한 209건(209/521, 40.12\%)을 분석한 결과 norovirus-GII 감염이 88건(88/521, 16.89\%), Campylobacter spp. 감염이 26건(26/521, 4.99\%), rotavirus 감염이 18건(18/521, 3.45\%), Clostridium difficile Toxin B 감염이 18 건(18/521, 3.45\%), adenovirus 감염이 17건(17/521, $3.26 \%$, Clostridium perfringens 감염은 16건(16/521, $3.07 \%$ ), astrovirus 감염은 11건(11/521, 2.11\%), Salmonella spp. 감염은 5건(5/521, 0.96\%), norovirus-GI, Yersinia spp., Aeromonas spp. 감염은 각각 3건(3/521, 0.58\%), verocytotoxin-producing E. coli 감염은 1건(1/521, 0.19\%), Vibrio $\mathrm{spp}$, E. coli $\mathrm{O} 157: \mathrm{H7}$, Shigella spp. 감염은 나타나지 않았다. 유아기(6세 이하)의 계절별 분리 양상을 확인한 결과는 기온이 낮은 겨울(11 2월)에는 주로 norovirus-GI, norovirus-GII 가 유행하였고, 기온이 상승하기 시작하는 봄(3 5월)에는 rotavirus가 유행하는 경향을 전형적인 장염바이러스의 경향을 보였다. Astrovirus 경우에는 norovirus-GI, norovirus-GII, rotavirus가 유행하는 시기가 아닌 4월 10월에 유행하는 경향 을 보이고, adenovirus인 경우에는 8월 2월까지 유행하는 경 향을 보였다. 연령이 높아질수록 바이러스뿐만 아니라 세균이 원인이 되어 급성설사질환을 유발하는 것으로 나타났으며, 다 중 중합효소연쇄반응으로 원인을 파악하고자 할 때에는 유아기 때에는 바이러스 검사를 의뢰하는 것이 유효하지만 연령이 높 아짐에 따라 바이러스와 세균을 동시에 의뢰하는 것이 바람직 하다고 사료된다.

\section{Acknowledgements: None \\ Funding: None \\ Conflict of interest: None}

\section{REFERENCES}

1. Seo GS, Choi SC. Diarrhea (Based on acute infectious diarrhea). Korean J Med. 2010;78(1):49-53.

2. Cheng AC, McDonald JR, Thielman NM. Infectious diarrhea in developed and developing countries. J Clin Gastroenterol 2005;39(9):757-773.

3. Daniel CP, Jan V, Peter GS, Kathryn ME, Mary AS, Geoffrey AW, et al. Norovirus and medically attended gastroenteritis in U.S children. N Engl J Med. 2013;368(12):1121-1130.

4. Fisher IS, Meakins S. Surveillance of enteric pathogens in Europe and beyond: Enter-net annual report for 2004. Euro Surveill. 2006;11(34):3032.

5. OzFoodNet Working Group. Enhancing foodborne disease surveillance across Australia in 2001: the OzFoodNet network, 2005. Comm Dis Intel. 2006;30(3):278-300.

6. Bowman C, Flint J, Pollari F. Canadian integrated surveillance report: Salmonella, Campylobacter, pathogenic E. coli and Shigella, from 1996 to 1999. 2003;29(Suppl 1):1-32.

7. Kim NO, Hong SH, Kwak HS. Prevalence and characteristics of bacteria causing acute diarrhea in Korea, 2012-2015. Public Health Weekly Report. 2016;9(46):922-928.

8. Clark B, McKendrick M. A review of viral gastroenteritis. Curr Opin Infect Dis. 2004;17(5):461-469.

9. Moon SK, Lee JI, Yoon HS, Ahn YM. Isolation rate of 4 type virus of acute gastroenteritis in full-term neonates during neonatal period. Korean J Pediatr. 2007;50(9):855-861.

10. Newell DG, Koopmans M, Verhoef L, Duizer E, Aidara-Kane A, Sprong H, et al. Food-borne diseases: The challenges of 20 years ago still persist while new ones continue to emerge. Int J Food Microbiol. 2010;139(Suppl 1):3-15.

11. Scallan E, Hoekstra RM, Angulo FJ, Tauxe RV, Widdowson MA, Roy SL, et al. Foodborne illness acquired in the United States: Major pathogens. Emerg Infect Dis. 2011;17(1):7-15.

12. Potasman I, Paz A, Odeh M. Infectious outbreaks associated with bivalve shellfish consumption: a worldwide perspective. 2002;35(8):921-929.

13. Takeshi T, Kuzuko N, Shinjiro H, Shuji N, Masatoshi T, Yoshiyuki $\mathrm{S}$, et al. Virological, serological, and clinical features of an outbreak of acute gastroenteritis due to recombinant genogroup II norovirus in an infant home. J Clin Microbiol. 2006;44(1): 177-182.

14. Midthun K, Kapikian AZ. Rotavirus vaccines: an overview. Clin Microbiol Rev. 1996;9(3):423-457.

15. Blacklow NR, Greenberg HB. Viral gastroenteritis. N Engl J Med. 1991;325(4):252-264.

16. Kim TH, Yim CH, Ahn SY, Kang KJ, Choi YM, Ko JH, et al. Clinical features of respiratory adenovirus infections in pediatric inpatients in a single medical center. Allergy Asthma Respir Dis. 2015;3(6):402-409.

17. Pai HJ. Acute infectious diarrhea. Korean J Med. 2007;73(1): 114-118. 
18. Park JJ. Enterohaemorrhagic E. coli O157:H7. Korean J Clin Lab Sci. 1996;28(1):235-241.

19. Sukhotnik I, Miron D, Kawar B, Yardeni D, Siplovich L. Perforated appendicitis in Shigellosis. Isr Med Assoc J. 1999;1(2): 124-125.

20. Daniels NA, MacKinnon L, Bishop R, Altekruse S, Ray B, Hammond R, et al. Vibrio parahaemolyticus infections in the United States, 1973-1998. J Infect Dis. 2000;181(5):1661-1666.

21. Ban MA. Campylobacter jejuni Infections: Update on Emerging Issues and Trends. Clinical Infectious Diseases. 2001;32(8): 1201-1206.

22. Ministry of Food and Drug Safety. Food poisoning statistics [Internet]. Seoul: Ministry of Food and Drug Safety; 2017 [cited 2017 April 26]. Available from: http://www.foodsafetykorea. go.kr/portal/healthyfoodlife/foodPoisoningStat.do?menu_ no=519\&menu_grp=MENU_GRP02.
23. Ma SH. Acute infectious diarrhea in pediatric patients. Korean J Pediatr. 2005;48(3):235-250.

24. Lee SO, Park YJ, Lee HK, Kim SY, Kim JY, Lee SY, et al. Detection of 13 enteric bacteria and 5 viruses causing acute infectious diarrhea using multiplex PCR from direct stool specimens. Ann Clin Microbiol. 2013;16(1):33-38.

25. Cho MC, Noh SA, Kim MN, Kim KM. Direct application of multiplex PCR on stool specimens for detection of enteropathogenic bacteria. Korean J Clin Microbiol. 2010;13(4):162168.

26. Hwang BM, Lee DY, Chung GT, Yoo CK. Laboratory surveillance of viral acute gastroenteritis in Korea, 2014. Public Health Weekly Report. 2015;8(49):1172-1177.

27. Shim JO. Differential diagnosis of acute diarrheal disorders in children. J Korean Med Assoc. 2012;55(6):516-524. 